\title{
INTERNATIONAL CONFERENCE ON CREATIVE AND INNOVATIVE TECHNOLOGY EDUCATION 2018
}

\author{
Norah Md Noor iD \\ Universiti Teknologi Malaysia (Malaysia) \\ norab@utm.my
}

Received September 2018

Accepted December 2018

\section{Introduction}

It is my great pleasure to present to you this special issue containing selected extended papers originally presented at the International Conference on Creative and Innovative Technology Education 2018 (iCITE2018), which took place in Johor Bahru, Malaysia from July 24 to July 25, 2018. iCITE2018 received 176 abstracts. 141 Authors of accepted abstracts were invited to submit full papers. Full papers were refereed by a double-blind reviewing process. Each paper was reviewed by 2 program committee members' experts in the relevant field ensuring the publication of top-quality contributions. The peer review process was based on the following criteria: relevance to conference themes, quality of the content, significance for theory or practice, quality of presentation or standard of writing and originality. The final programme consists of 67 contributions were presented at the conference. Of those, 10 have been accepted to be included in this issue. I would like to thank all publication committee and reviewers for their hard work and for meeting the deadlines. In most cases there has been enough time for a round or two of revisions, I am confident, therefore, that the published papers have achieved high standard in terms of both technical content and the quality of presentation.

This special issue includes study in teaching and learning experienced by researcher from Malaysia, Indonesia, Thailand, Oman and Argentina. As learning has grown from traditional to online courses, educators are still thinking and researching on the factors that could influence student engagement (Chen, Lambert \& Guidry, 2010; Pellas, 2014). Even in MOOCs courses, the attainment level of students are still an ongoing issues (Kizilcec, Pérez-Sanagustín \& Maldonado, 2017; Onah, Sinclair \& Boyatt, 2014). Two of the papers in this issue focus on Social Interaction among students and instructors within the online learning environment. The first paper by Wan Nur Tasnim et al. focus on designing a framework to assist other practitioners and researchers in applying the elements of online interaction in a social learning environment to foster students' critical thinking skill. While the second paper by Yahya M. Al-Dheleai and Zaidatun Tasir discuss about social presence differences among genders as social presence (SP) is an important component of effective learning in both face-face and online learning environment.

Another focus in this issue are teaching method which educators and researcher believe that a suitable strategy can also increase engagement among students either in the face to face or online (Da Rocha Seixas, Gomes \& De Melo Filho, 2016; Dobozy, 2012; Hanus \& Fox, 2015; Stone, 2012). One of the popular strategy used nowadays is game either game-based learning or even gamification strategy that able to create an active and fun learning atmosphere. Using a data mining technique, Sakchai Muangsrinoon and Poonpong Boonbrahm identified game elements and its relationship with self Determination Theory 
(STD). Their finding will become the basis for a new gamified system in the online learning environment. Another paper by Deasy Arisanty and Riyah also used a game technique that motivates students to find pairs of cards containing matching questions and answers in their Geography class which is Make-a-match model. Their study found that students not only motivated, but also performed better.

The paper by Mohammed F.M. Abushammala discuss flipped classroom strategy. Although this strategy has been around for many years (Bergmann \& Sams, 2011; Bishop \& Verleger, 2013; Lai \& Hwang, 2016; Tune, Sturek \& Basile, 2013), educators still experimenting the best way to ensure this strategy help students learning efficiently. His paper explains how the learning was conducted using various technology tools, and students were found to be interested in the planned classroom activities resulting in an effective and deep learning process. Another paper from Siti Najihah, Nor Hasniza and Johari focus on concept cartoon as a teaching strategy. Their review study found that concept cartoon in a problem-based learning approach does have the potential to increase creativity and innovation as well as the students' interest in understanding concepts. However, paper by Rusmansyah et al. claim that problem-based learning still has some weaknesses to promote ciritcal thinking skills. So, their paper focus on developing Scientific Critical Thinking (SCT) Learning Model based on strengths and weaknesses of PBL model and Inquiry model which was tested among the pre-service chemistry teachers.

One of the 21 st-century skills that is important to be nurtured among the younger generation is scientific reasoning skills. It is one of the skills tested In the PISA test. However, the paper by Mustika Wati et al. shows that 201 students from the eighth-grade junior high school in Banjarmasin selected at random, had a low level of scientific reasoning ability. So, educators should strive to improve students' scientific reasoning abilities in the classroom. Maybe, by using Latent Semantic Indexing (LSI) method proposed by Muhammad Said et al. to identify the personality of the learner based on their prior knowledge might be able to guide educators finding the best approach to support students understanding. Or, if a collaborative work, ICT and teaching are integrated to create collaborative learning environments assisted by computer (CSCL) suggested by Battaglia et al. can be made into realization, we can explore more on how it can help enhance students learning outcome, not only on performance but also on other soft skills needed in the 21 st century that overcomes the traditional method.

I hope that all paper appears in this special issue can spark a new idea among educators and provide new gaps among researcher for a better education all around the world.

\section{Declaration of Conflicting Interests}

The author declared no potential conflicts of interest with respect to the research, authorship, and/or publication of this article.

\section{Funding}

The author received no financial support for the research, authorship, and/or publication of this article.

\section{References}

Bergmann, J., \& Sams, A. (2011). How the flipped classroom was born. The Daily Riff Online.

Bishop, J., \& Verleger, M. (2013). The flipped classroom: A survey of the research. ASEE National Conference Proceedings, Atlanta .... Retrieved from http://www.asee.org/file_server/papers/attachment/file/0003/3259/6219.pdf

Chen, P.-S. D., Lambert, A. D., \& Guidry, K. R. (2010). Engaging online learners: The impact of Webbased learning technology on college student engagement. Computers \& Education, 54(4), 1222-1232.

Da Rocha Seixas, L., Gomes, A. S., \& De Melo Filho, I. J. (2016). Effectiveness of gamification in the engagement of students. Computers in Human Behavior, 58, 48-63. https://doi.org/10.1016/j.chb.2015.11.021 
Dobozy, E. (2012). Failled Innovation Implementation in teacher education: A case analysis. Problems of Education in the 21stCentury, 40.

Hanus, M. D., \& Fox, J. (2015). Assessing the effects of gamification in the classroom: A longitudinal study on intrinsic motivation, social comparison, satisfaction, effort, and academic performance. Computers and Education, 80, 152-161. https://doi.org/10.1016/j.compedu.2014.08.019

Kizilcec, R. F., Pérez-Sanagustin, M., \& Maldonado, J. J. (2017). Self-regulated learning strategies predict learner behavior and goal attainment in Massive Open Online Courses. Computers \& Education, 104, 18 33.

Lai, C.-L., \& Hwang, G.-J. (2016). A self-regulated flipped classroom approach to improving students' learning performance in a mathematics course. Computers \& Education, 100, 126-140. https://doi.org/10.1016/j.compedu.2016.05.006

Onah, D. F. O., Sinclair, J., \& Boyatt, R. (2014). Dropout rates of massive open online courses: behavioural patterns. EDULEARN14 Proceedings, 5825-5834.

Pellas, N. (2014). The influence of computer self-efficacy, metacognitive self-regulation and self-esteem on student engagement in online learning programs: Evidence from the virtual world of Second Life. Computers in Human Behavior, 35, 157-170.

Stone, B. B. (2012). Flip your classroom to increase active learning and student engagement. In Proceedings from 28th Annual Conference on Distance Teaching and Learning.

Tune, J. D., Sturek, M., \& Basile, D. P. (2013). Flipped classroom model improves graduate student performance in cardiovascular, respiratory, and renal physiology. Advances in Physiology Education, 37(4), 316-320. https://doi.org/10.1152/advan.00091.2013

\section{To cite this article:}

Noor, N.Md. (2019). International Conference on Creative and Innovative Technology Education 2018. Journal of Technology and Science Education, 9(1), 1-3. https://doi.org/10.3926/jotse.537

Published by OmniaScience (www.omniascience.com)

Journal of Technology and Science Education, 2019 (www.jotse.org)

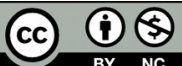

Article's contents are provided on an Attribution-Non Commercial 4.0 Creative commons International License. Readers are allowed to copy, distribute and communicate article's contents, provided the author's and JOTSE journal's names are included. It must not be used for commercial purposes. To see the complete licence contents, please visit https://creativecommons.org/licenses/by-nc/4.0/. 